\title{
The Present Value of Human Life Losses Associated with Coronavirus Disease in Africa
}

\section{Joses Muthuri Kirigia ${ }^{{ }^{*}}$, Rose Nabi Deborah Karimi Muthuri ${ }^{2}$, Lenity Honesty Kainyu Nkanata ${ }^{1}$, Newton Gitonga Muthuri ${ }^{3}$}

\author{
${ }^{1}$ African Sustainable Development Research Consortium (ASDRC), Nairobi, Kenya \\ ${ }^{2}$ Faculty of Health Sciences, University of Pretoria, Pretoria, South Africa \\ ${ }^{3}$ Chandaria School of Business, United States International University-Africa, Nairobi, Kenya \\ Email: *muthurijoses68@gmail.com
}

How to cite this paper: Kirigia, J. M., Muthuri, R. N. D. K., Nkanata, L. H. K., \& Muthuri, N. G. (2020). The Present Value of Human Life Losses Associated with Coronavirus Disease in Africa. Open Journal of Business and Management, 8, 2371-2395. https://doi.org/10.4236/ojbm.2020.86146

Received: October 2, 2020

Accepted: October 27, 2020

Published: October 30, 2020

Copyright $\odot 2020$ by author(s) and Scientific Research Publishing Inc. This work is licensed under the Creative Commons Attribution International License (CC BY 4.0).

http://creativecommons.org/licenses/by/4.0/

\begin{abstract}
The coronavirus disease (COVID-19) continues to ravage human lives, social systems, and economies around the world. The objective of this study was to estimate the total present value $\left(\mathrm{TPV}_{\mathrm{AFC}}\right)$ of human life losses associated with COVID-19 in Africa continent as of 1 August 2020. A human capital approach model was used to estimate the $\mathrm{TPV}_{\mathrm{AFC}}$ of the 19,682 human lives lost due to COVID-19 in Africa continent (excluding 44 deaths in Sahrawi Arab Democratic Republic and territories of Mayotte and Reunion). The average life expectancy for 54 countries with data and a 3\% discount rate were used. A sensitivity analysis was conducted at $5 \%$ and $10 \%$ discount rates. The human lives lost due to COVID-19 had a $\mathrm{TPV}_{\mathrm{AFC}}$ of Int $\$ 1,721,030,766$, and average $\mathrm{TPV}_{\mathrm{AFC}}$ of Int $\$ 87,442$ per human life lost. About $81.3 \%$ of $\mathrm{TPV}_{\mathrm{AFC}}$ accrued to persons below 60 years. The TPV $\mathrm{AFC}_{\mathrm{AF}}$ of human life losses from COVID-19 will continue growing until the pandemic is eradicated.
\end{abstract}

\section{Keywords}

Coronavirus, COVID-19, Gross Domestic Product, Value of Human Life

\section{Introduction}

Africa continent has 55 countries (plus territories of Mayotte and Reunion), with an estimated total population of $1,340,598,113$ persons (17.2\% of the global population) in 2020 (Worldometer, 2020). The continent has an estimated gross domestic product (GDP) of Int $\$ 7.6$ trillion and a per capita GDP of Int $\$ 5720$ in 2020 (International Monetary Fund (IMF), 2020).

As of 1 August 2020, the world had a total of 17,757,496 confirmed coronavi- 
rus disease (COVID-19) cases, among them 682,998 deaths, 11,160,054 recovered cases, and 5,914,444 active cases (Worldometer, 2020). By the same date, all countries and territories in Africa had reported a total of 931,777 confirmed cases, including 19,726 deaths, 583,665 recovered cases, and 328,386 active cases. In Africa, COVID-19 deaths varied widely from one in the Sahrawi Arab Democratic Republic to 8005 in South Africa (Worldometer, 2020).

Africa's capability of containing the spread of COVID-19 depends on the resilience of national health systems (NHS), disease surveillance and response systems (DSRS), and other systems that tackle social determinants of health (SDHS). The universal health coverage (UHC) service index (a proxy for NHS) for the WHO African Region (AFR) was 46 (on a scale of 0 to target of 100), and that of the WHO Eastern Mediterranean Region (EMR) was 57 in 2017, which implied the existence of gaps in essential health services coverage of 54 and 43, respectively (WHO and The World Bank, 2017). Among the Africa continent countries, the UHC index gap varied widely from 22 in Algeria to 75 in Somalia in 2019 (Kirigia, Rutere, Muthuri, \& Kirigia, 2020).

The average of International Health Regulations [IHR] (a proxy for DSRS) core capacity scores for AFR was 44\% and 66\% for EMR in 2019, denoting IHR gaps of $56 \%$ and $34 \%$, respectively (WHO, 2013, 2020a). The population using a hand-washing facility with soap and water (a proxy for the SDHS) in AFR was $28 \%$ and $66 \%$ in EMR in 2017, signifying gaps of $72 \%$ and $34 \%$, respectively (WHO, 2020a). The population without basic hand-washing facilities in Africa varied from 10\% in Egypt to 99\% in Liberia in 2017 (Rutere, Muthuri, Kirigia, \& Kirigia, 2020).

According to Rice (2000), "cost of illness studies translates the adverse effects of diseases or injuries into dollar terms, the universal language of decision-makers and the policy arena" (p. 178). Studies in Canada (Kirigia \& Muthuri, 2020a), China (Kirigia \& Muthuri, 2020b), Spain (Kirigia \& Muthuri, 2020c), Turkey (Kirigia, Muthuri, \& Nkanata, 2020), the United Kingdom [UK] (Kirigia \& Muthuri, 2020d), and the United States of America [USA] (Kirigia \& Muthuri, 2020e) assessed the monetary value of human life losses associated with COVID-19 for use in advocacy for increased investments in NHS, DSRS, and SDHS to combat current and future pandemics. There is a dearth of evidence on the total present value (TPV $\mathrm{AFC}$ ) of human lives lost due to COVID-19 in the continent. This study estimated the $\mathrm{TPV}_{\mathrm{AFC}}$ of human life losses associated with COVID-19 in the Africa continent as of 1 August 2020.

\section{Materials and Methods}

\subsection{Ethical Considerations}

The study did not require ethical approval since it relied exclusively on secondary data from international databases that are in the public domain (Worldometer, 2020; International Monetary Fund (IMF), 2020; WHO, 2019, 2020b). 


\subsection{Study Location and Design}

This study encompassed 54 countries of the Africa continent. The Sahrawi Arab Democratic Republic (Western Sahara) was excluded because data on GDP per capita and current health expenditure per capita was missing. It was a cross-sectional assessment of the monetary value of all the 19,682 human life losses associated with COVID-19 as of 1 August 2020 (Worldometer, 2020). Since the study involved the cumulative number of deaths up to 1 August 2020, sampling was not relevant.

\subsection{Analytical Framework}

Three approaches exist for monetary valuation of a statistical life, i.e. the human capital approach (HCA), the revealed preferences approach, and the willingness-to-pay approach (WTP) (Jones-Lee, 1985). The HCA was applied in the current study to value human life losses associated with COVID-19 in Africa due to the availability of relevant data.

The HCA employed in the current study owes its antecedents to the seminal work of Landefeld and Seskin (1982). Weisbrod (1961) and WHO (2009a) clarified that human life is to be valued using discounted future earnings net of the individual's consumption. Any premature death from COVID-19 (or any other cause) results in potential years of life lost (YLL), which are equal to the average life expectancy at birth for a specific country minus the age of onset of death (Kirigia \& Muthuri, 2020a, 2020b, 2020c, 2020d, 2020e; Kirigia, Muthuri, \& Nkanata, 2020). In line with Weisbrod (1961) and WHO (2009a), the net per capita GDP (i.e., specific country's per capita GDP minus current health expenditure per person) is used in monetary valuation of YLL.

The economic model used in the current study was that applied to estimate discounted monetary value human life losses associated with COVID-19 in Canada (Kirigia \& Muthuri, 2020a), China (Kirigia \& Muthuri, 2020b), Spain (Kirigia \& Muthuri, 2020c), Turkey (Kirigia, Muthuri, \& Nkanata, 2020), the UK (Kirigia \& Muthuri, 2020d), and the USA (Kirigia \& Muthuri, 2020e).

The $\mathrm{TPV}_{\mathrm{AFC}}$ is the sum of present value of human lives lost from COVID-19 as of $1^{\text {st }}$ August 2020 in each of the 54 countries $\left(\mathrm{CPV}_{j=1, \cdots, 55}\right)$. That is:

$$
\mathrm{TPV}_{\mathrm{AFC}}=\mathrm{CPV}_{1}+\mathrm{CPV}_{2}+\mathrm{CPV}_{3}+\cdots+\mathrm{CPV}_{j}
$$

The present value of human lives lost through COVID-19 in the th country $\left(\mathrm{CPV}_{j=1, \cdots, 55}\right)$ is the sum of the discounted present value of lives lost among the 0 - 9-year-olds $\left(\mathrm{PV}_{0-9}\right), 10$ - 19-year-olds $\left(\mathrm{PV}_{10-19}\right), 20$ - 29-year-olds $\left(\mathrm{PV}_{20-29}\right), 30$ 39-year-olds $\left(\mathrm{PV}_{30-39}\right), 40$ - 49-year-olds $\left(\mathrm{PV}_{40-49}\right), 50$ - 59-year-olds $\left(\mathrm{PV}_{50-59}\right), 60$ 69-year-olds $\left(\mathrm{PV}_{60-69}\right)$, and the 70-year-olds and above $\left(\mathrm{PV}_{\geq 70}\right)$ (Kirigia \& Muthuri, 2020a, 2020b, 2020c, 2020d, 2020e; Kirigia, Muthuri, \& Nkanata, 2020). Formally:

$$
\mathrm{CPV}_{j}=\sum_{i=1}^{I} \mathrm{PV}_{i}
$$


The $i^{\text {th }}$ age group present value $\left(\mathrm{PV}_{i}\right)$ equals a product of discount factor, YLL, net per capita GDP (NPCGDP), and COVID-19 deaths for age group (Kirigia \& Muthuri, 2020a, 2020b, 2020c, 2020d, 2020e; Kirigia, Muthuri, \& Nkanata, 2020). That is:

$$
\mathrm{PV}_{i=1, \cdots, 9}=\sum_{t=1}^{T} A_{1} \times\left(A_{2}-A_{3}\right) \times\left(A_{4}-A_{5}\right) \times\left(A_{6} \times A_{7}\right)
$$

where: $A_{1}$ is the discount factor obtained using the formula $1 /(1+r)^{t}, r$ is the discount rate, which was 3\% in the current study (Kirigia \& Muthuri, 2020a, 2020b, 2020c, 2020d, 2020e; Kirigia, Muthuri, \& Nkanata, 2020); $\sum_{t=1}^{t=n}$ is the summation from year $t=1$ to $T$; $t$ is the first YLL and $T$ is the final year of the total number of YLL per COVID-19 human life lost within an age group; $A_{2}$ is the per capita GDP for a specific country in International Dollars (Int) or Purchasing Power Parity (PPP); $A_{3}$ is the current health expenditure per person for a specific country; $A_{4}$ is the average life expectancy at birth for a specific country; $A_{5}$ is the average age of onset of death for each age group; $A_{6}$ is the total number of human lives lost from COVID-19 in a specific country; $A_{7}$ is the proportion of COVID-19 human lives lost borne by a specific age group. The base year for the analysis was 2020. Equations 1, 2 and 3 were estimated using the Excel Software (Microsoft, New York, USA).

\subsection{Sensitivity Analysis}

The economic model was reanalyzed three times assuming 1) $5 \%$ and $10 \%$ discount rates (Kirigia \& Muthuri, 2020a, 2020b, 2020c, 2020d, 2020e; Kirigia, Muthuri, \& Nkanata, 2020); and 2) the world's highest life expectancy of 87.17 years in 2020 (i.e., Hong Kong's average female life expectancy at birth) to gauge the impact on $\mathrm{TPV}_{\mathrm{AFC}}$ (Worldometer, 2020). After each rerun of the economic model, the change was calculated by subtracting the original TPV estimate $\left(\mathrm{TPV}_{\mathrm{OLD}}\right)$ from the new TPV estimate $\left(\mathrm{TPV}_{\mathrm{NEW}}\right)$. The percentage change equals the change in TPV divided by the original TPV OLD estimate, multiplied by 100 . Algebraically:

$$
\text { Percentage change }=\frac{\left(\mathrm{TPV}_{\mathrm{NEW}}-\mathrm{TPV}_{\mathrm{OLD}}\right)}{\left|\mathrm{TPV} \mathrm{OLD}_{\mathrm{OL}}\right|} \times 100
$$

For example, in this study, $\mathrm{TPV}_{\mathrm{OLD}}=\mathrm{Int} \$ 1,721,030,766$; and following a reanalysis of the HCA model with the world highest life expectancy the $\mathrm{TPV}_{\mathrm{NEW}}=$ Int $\$ 4,064,146,193$. Thus:

$$
\text { Percentage change }=\frac{(4064146193-1721030766)}{|1721030766|} \times 100=136.1 \%
$$

\subsection{Data and Data Sources}

The analysis included 54 countries in the African continent (see Table S1 for the names). The Sahrawi Arab Democratic Republic (Western Sahara) and the territories of Mayotte and Reunion (which had a total of 44 COVID-19 deaths) 
were excluded because of missing data on per capita GDP (International Monetary Fund (IMF), 2020) and current health expenditure per person (WHO, 2020b). The discount rates of $3 \%, 5 \%$, and $10 \%$ were from recent studies that estimate the monetary value of human life losses associated with COVID-19 (Kirigia \& $\mathrm{Mu}-$ thuri, 2020a, 2020b, 2020c, 2020d, 2020e; Kirigia, Muthuri, \& Nkanata, 2020).

The average life expectancies at birth for each of the 54 countries and the world's highest life expectancy of 88.17 years in 2020 were from the Worldometer database (see Table S2) (Worldometer, 2020). The ages of onset of death were 4.5 years for group 0 - 9 years, i.e. $[0+9) / 2 ; 14.5$ years for group $10-19$ years; 24.5 years for group 20 - 29 years; 34.5 years for group 30 - 39 years; 44.5 years for group 40 - 49 years; 54.5 years for group 50 - 59 years; 64.5 years for group 60 - 69 years; and 70 years for group 70 years and above.

The data on per capita GDP expressed in International Dollars (Int\$) (or Purchasing Power Parity) in 2020 for each of the 54 countries were from IMF World Economic Outlook Database (see Table S3) (International Monetary Fund (IMF), 2020). The 2017 (latest available) data on current health expenditures per person for each of the 54 countries were collated from the WHO Global Health Expenditure Database (see Table S4) (WHO, 2020b). The estimated NPCGDP data is in Table S5.

Data on the total number of COVID-19 deaths as of 1 August 2020 for each of the 54 countries were from the Worldometer database (see Table S6) (Worldometer, 2020). The proportions used to share the number of COVID-19 deaths in each country across the eight age groups was calculated using 2020 data from Statista database (see Table S7) (WHO, 2019). The estimated YLL by age group per country are in Table S8.

\section{Results}

\subsection{Findings Assuming Each Country's Life Expectancy at Birth and a 3\% Discount Rate}

Table 1 presents the discounted value of human lives lost from COVID-19 in continental Africa by 1 August 2020.

The 19,682 human lives lost (equal to 198,575 YLL) due to COVID-19 in Africa had $\mathrm{TPV}_{\mathrm{AFC}}$ of Int $\$ 1,721,030,766$. Out of which, approximately $0.6 \%$ accrued to 0 - 9-year-olds, $0.9 \%$ to 10 - 19 -year-olds, $4.1 \%$ to 20 - 29-year-olds, $15.8 \%$ to 30 - 39 -year-olds, $26.5 \%$ to 40 - 49 -year-olds, $33.4 \%$ to 50 59 -year-olds, $12.9 \%$ to 60 - 69 -year-olds, and $5.8 \%$ to the 70 -year-olds and above. The average was Int $\$ 87,442$ per human life lost due to COVID-19; and Int $\$ 1.29$ per person in the population.

As shown in Figure 1, the CPV of human lives lost varied widely from Int $\$ 0$ in Eritrea and Seychelles (where there were no reported COVID-19 deaths) to Int\$697,921,220 in Egypt.

Twenty-eight (52\%) countries had CPV of less than Int\$1 million, 20 (37\%) 
countries had between Int $\$ 1$ million and Int $\$ 10$ million, and six (11\%) countries had Int\$11 million and above. Three countries (Algeria, Egypt, and South Africa) accounted for $90 \%$ of the $\mathrm{TPV}_{\mathrm{AFC}}$ of human lives lost in the continent.

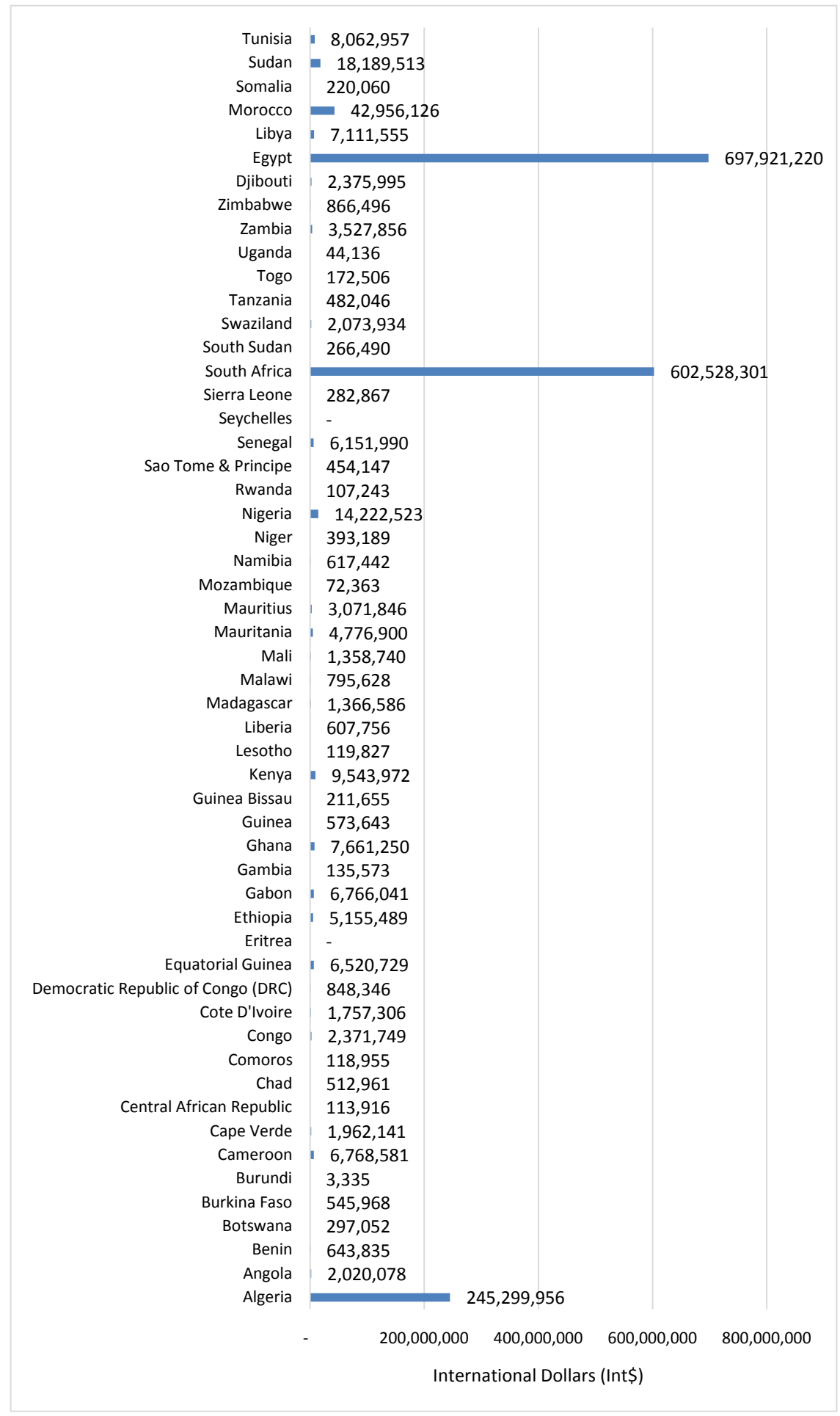

Figure 1. Present value of human life losses associated with COVID-19 in Africa by 1 August 2020 (in International Dollars). 
Table 1. The present value of human life losses from COVID-19 in Africa as of 1 August 2020 (in 2020, Int\$ or PPP).

\begin{tabular}{|c|c|c|c|c|c|}
\hline Country & $\begin{array}{l}\text { Population } \\
\text { in } 2020^{*} \text { [A] }\end{array}$ & $\begin{array}{l}\text { COVID-19 deaths } \\
\text { as of } 1 \text { August } \\
2020^{*}[\mathrm{~B}]\end{array}$ & $\begin{array}{l}\text { Total present value } \\
\text { of human life lost } \\
\text { (Int\$) [C] }\end{array}$ & $\begin{array}{c}\text { Present value per } \\
\text { human life lost (Int\$) } \\
{[\mathrm{D}=\mathrm{C} / \mathrm{B}]^{* *}}\end{array}$ & $\begin{array}{l}\text { Present value of human life } \\
\text { lost per person in population } \\
\text { (Int\$) }[\mathrm{E}=\mathrm{C} / \mathrm{A}]^{* *}\end{array}$ \\
\hline Algeria & $43,851,043$ & 1210 & $245,299,956$ & 202,727 & 5.59 \\
\hline Angola & $32,866,268$ & 52 & $2,020,078$ & 38,848 & 0.06 \\
\hline Benin & $12,123,198$ & 36 & 643,835 & 17,884 & 0.05 \\
\hline Botswana & $2,351,625$ & 2 & 297,052 & 148,526 & 0.13 \\
\hline Burkina Faso & $20,903,278$ & 53 & 545,968 & 10,301 & 0.03 \\
\hline Burundi & $11,890,781$ & 1 & 3335 & 3335 & 0.00 \\
\hline Cameroon & $26,545,864$ & 391 & $6,768,581$ & 17,311 & 0.25 \\
\hline Cape Verde & 555,988 & 23 & $1,962,141$ & 85,310 & 3.53 \\
\hline $\begin{array}{l}\text { Central African } \\
\text { Republic }\end{array}$ & $4,829,764$ & 59 & 113,916 & 1931 & 0.02 \\
\hline Chad & $16,425,859$ & 75 & 512,961 & 6839 & 0.03 \\
\hline Comoros & 869,595 & 7 & 118,955 & 16,994 & 0.14 \\
\hline Congo & $5,518,092$ & 54 & $2,371,749$ & 43,921 & 0.43 \\
\hline Cote d'Ivoire & $26,378,275$ & 102 & $1,757,306$ & 17,228 & 0.07 \\
\hline $\begin{array}{c}\text { Democratic Republic } \\
\text { of Congo (DRC) }\end{array}$ & $89,561,404$ & 215 & 848,346 & 3946 & 0.01 \\
\hline Equatorial Guinea & $1,402,985$ & 83 & $6,520,729$ & 78,563 & 4.65 \\
\hline Eritrea & $3,546,427$ & 0 & 0 & 0 & 0 \\
\hline Ethiopia & $114,963,583$ & 274 & $5,155,489$ & 18,816 & 0.04 \\
\hline Gabon & $2,225,728$ & 49 & $6,766,041$ & 138,082 & 3.04 \\
\hline Gambia, The & $2,416,664$ & 9 & 135,573 & 15,064 & 0.06 \\
\hline Ghana & $31,072,945$ & 182 & $7,661,250$ & 42,095 & 0.25 \\
\hline Guinea & $13,132,792$ & 46 & 573,643 & 12,471 & 0.04 \\
\hline Guinea-Bissau & $1,967,998$ & 26 & 211,655 & 8141 & 0.11 \\
\hline Kenya & $53,771,300$ & 341 & $9,543,972$ & 27,988 & 0.18 \\
\hline Lesotho & $2,142,252$ & 13 & 119,827 & 9217 & 0.06 \\
\hline Liberia & $5,057,677$ & 75 & 607,756 & 8103 & 0.12 \\
\hline Madagascar & $27,691,019$ & 106 & $1,366,586$ & 12,892 & 0.05 \\
\hline Malawi & $19,129,955$ & 114 & 795,628 & 6979 & 0.04 \\
\hline Mali & $20,250,834$ & 124 & $1,358,740$ & 10,958 & 0.07 \\
\hline Mauritania & $4,649,660$ & 157 & $4,776,900$ & 30,426 & 1.03 \\
\hline Mauritius & $1,271,767$ & 10 & $3,071,846$ & 307,185 & 2.42 \\
\hline Mozambique & $31,255,435$ & 11 & 72,363 & 6578 & 0.00 \\
\hline Namibia & $2,540,916$ & 10 & 617,442 & 61,744 & 0.24 \\
\hline Niger & $24,206,636$ & 69 & 393,189 & 5698 & 0.02 \\
\hline
\end{tabular}


Continued

\begin{tabular}{|c|c|c|c|c|c|}
\hline Nigeria & $206,139,587$ & 879 & $14,222,523$ & 16,180 & 0.07 \\
\hline Rwanda & $12,952,209$ & 5 & 107,243 & 21,449 & 0.01 \\
\hline Sao Tome and Principe & 219,161 & 15 & 454,147 & 30,276 & 2.07 \\
\hline Senegal & $16,743,930$ & 205 & $6,151,990$ & 30,010 & 0.37 \\
\hline Ghana & $31,072,945$ & 182 & $7,661,250$ & 42,095 & 0.25 \\
\hline Seychelles & 98,340 & 0 & 0 & 0 & 0 \\
\hline Sierra Leone & $7,976,985$ & 67 & 282,867 & 4222 & 0.04 \\
\hline South Africa & $59,308,690$ & 8005 & $602,528,301$ & 75,269 & 10.16 \\
\hline South Sudan & $11,193,729$ & 46 & 266,490 & 5793 & 0.02 \\
\hline Swaziland (Eswatini) & $1,160,164$ & 41 & $2,073,934$ & 50,584 & 1.79 \\
\hline Tanzania & $59,734,213$ & 21 & 482,046 & 22,955 & 0.01 \\
\hline Togo & $8,278,737$ & 19 & 172,506 & 9079 & 0.02 \\
\hline Uganda & $45,741,000$ & 3 & 44,136 & 14,712 & 0.00 \\
\hline Zambia & $18,383,956$ & 151 & $3,527,856$ & 23,363 & 0.19 \\
\hline Zimbabwe & $14,862,927$ & 67 & 866,496 & 12,933 & 0.06 \\
\hline Djibouti & 988,002 & 58 & $2,375,995$ & 40,965 & 2.40 \\
\hline Egypt & $102,334,403$ & 4805 & $697,921,220$ & 145,249 & 6.82 \\
\hline Libya & $6,871,287$ & 74 & $7,111,555$ & 96,102 & 1.03 \\
\hline Morocco & $36,910,558$ & 353 & $42,956,126$ & 121,689 & 1.16 \\
\hline Somalia & $15,893,219$ & 93 & 220,060 & 2366 & 0.01 \\
\hline Sudan & $43,849,269$ & 746 & $18,189,513$ & 24,383 & 0.41 \\
\hline Tunisia & $11,818,618$ & 50 & $8,062,957$ & 161,259 & 0.68 \\
\hline TOTAL & $1,338,826,591$ & 19,682 & $1,721,030,766$ & 87,442 & 1.29 \\
\hline
\end{tabular}

Source: ${ }^{*}$ Worldometer $(2020) .{ }^{*}$ Authors estimates.

\subsection{Findings Assuming Each Country's Life Expectancy and 5\% and $10 \%$ Discount Rates}

Alternate reanalysis of the economic model (in subsection 2.3) using 5\% and $10 \%$ discount rates reduced the $\mathrm{TPV}_{\mathrm{AFC}}$ by $\operatorname{Int} \$ 273,841,437$ (15.9\%) and Int $\$ 695,688,478(40.4 \%)$, respectively. In turn, the average present value per human life diminished by Int $\$ 13,913.3$ and Int $\$ 35,346$.

\subsection{Findings Assuming World Highest Life Expectancy and 3\% Discount Rate}

Re-calculation of the economic model (in subsection 2.3) substituting individual country's national life expectancy with the world highest life expectancy of 88.17 years increased the $\mathrm{TPV}_{\mathrm{AFC}}$ by Int $\$ 2,343,115,427$ (136.1\%) and the present value per human life by Int $\$ 119,049$. 


\section{Discussion}

\subsection{Key Findings}

Our study succeeded in estimating the $\mathrm{TPV}_{\mathrm{AFC}}$ of human lives lost due to COVID-19 in the Continent as of 1 August 2020. The $\mathrm{TPV}_{\mathrm{AFC}}$ of Int $\$ 1,721,030,766$ was equivalent to $0.023 \%$ of the total GDP of the African Continent. The present value of Int $\$ 87,442$ per human life loss associated with COVID-19 was 15-fold Africa's GDP per capita in 2020.

\subsection{Comparison with Similar Studies}

The present value per human life lost from COVID-19 in Africa was lower than Canada’s Int $\$ 231,217$ per death (Kirigia \& Muthuri, 2020a), China’s Int $\$ 356,203$ per death (Kirigia \& Muthuri, 2020b), Spain's Int $\$ 470,798$ per death (Kirigia \& Muthuri, 2020c), Turkey’s Int $\$ 228,514$ per death (Kirigia, Muthuri, \& Nkanata, 2020), the UK’s Int $\$ 225,104$ per death (Kirigia \& Muthuri, 2020d), and the USA's Int $\$ 292,889$ per death (Kirigia \& Muthuri, 2020e). The lower present value per human life lost in Africa may be due to both lower GDP per capita, and lower life expectancy at birth (leading to a smaller number of YLL) (Kirigia \& Muthuri, 2020a, 2020b, 2020c, 2020d, 2020e).

\subsection{Research Innovation}

To the best of our knowledge, this was the first study to have estimated the present value of human life losses associated with coronavirus disease in Africa. As explained in the WHO guide to identifying the economic consequences of disease and injury (WHO, 2009a), the evidence contained in this article can be used by the ministries of health in African countries to advocate for increased investments into health-related sectors to bridge existing gaps in the coverage of essential health services, IHR core capacities, and water and sanitation services.

\subsection{Study Limitations}

First, the completeness of cause-of-death data in the AFR was $6 \%$ and $32 \%$ in EMR, implying cause-of-death for $94 \%$ and $68 \%$ of deaths, respectively, is not recorded (WHO, 2019). The relatively low completeness of cause-of-death during the ordinary non-pandemic period implies that the notified COVID-19 cases and deaths could be a gross underestimate for many African countries. The under-reporting is exacerbated by the low level of COVID-19 testing in Africa (Worldometer, 2020).

Second, the cost of societal resources used in the prevention, diagnosis, contact tracing, isolation/quarantine, hospital management of COVID-19 cases; and funerals for the dead was omitted (Kirigia \& Muthuri, 2020a, 2020b, 2020c, 2020d, 2020e; Kirigia, Muthuri, \& Nkanata, 2020). Third, the macroeconomic effects of COVID-19 on education, financial services, trade, tourism, travel, and manufacturing sectors were omitted (Kirigia, Muthuri, \& Nkanata, 2020). 
Fourth, according to Jones-Lee (1985) the HCA when strictly applied, it would value YLL among retirees and homemakers at zero. Jones-Lee (1985) advocates for elicitation of WTP for small changes in probability death (e.g. from COVID-19) because the approach " $\ldots$ is firmly rooted in the principles of ex-ante Paretian welfare economics and the related precepts of conventional social cost-benefit analysis (p. 143)".

\subsection{Future Research Directions}

First, the quality of economic evaluation studies hinges on the quality of underlying epidemiological evidence. Thus, there is need for quality epidemiological studies on morbidity and mortality due to pandemics; effectiveness of existing and potential preventive, diagnostic, management, and rehabilitative interventions from randomized controlled effectiveness trials; effectiveness of alternative ways of delivering interventions; and human behaviour in intervention uptake and adherence to recommended procedures.

Second, once the pandemic is eradicated, there will be a need for comprehensive studies into the macroeconomic effects of COVID-19 on education, financial services, trade, tourism, travel, manufacturing, and other sectors. Such evidence could be used in advocating for coordinated and managed inter-sectoral action for implementation of health-in-all policies to leapfrog equitable health development, mitigate, and better combat future public health emergencies (WHO, 2009b, 2010, 2012a, 2012b).

Third, the health policy development and decision-making processes require evidence on both costs and consequences (or benefits) of preventive, management, and rehabilitative interventions for COVID-19 (Drummond, Sculpher, Torrance, O’Brien, \& Stoddard, 2007; Kirigia, 2009; Cookson, Griffin, Norheim, \& Culyer, 2020). For comparative purposes, future studies should consider applying the WTP approach to value human life losses associated with COVID-19, which would facilitate comparison with those obtained in the current study using the HCA.

\section{Conclusion}

The estimated $\mathrm{TPV}_{\mathrm{AFC}}$ of human lives lost due to COVID-19 in Africa is likely to be an underestimate due to abovementioned limitations. COVID-19 is a burden on the NHS, the DSRS, the SDHS, and the economies of African countries. The $T_{P V} V_{A F C}$ will continue growing until the pandemic is eradicated. The $T P V_{A F C}$ evidence, in conjunction with human rights arguments (rights to life, health, medical care, clothing, food, housing, and social security) (United Nations (UN), 1948), can be used in advocacy for increased domestic and external investments to bridge existing gaps in NHS, DSRS, and SDHS. Since our study was of limited scope, assessments of the economy-wide impact of COVID-19; and costs and consequences of preventive, treatment, and rehabilitative interventions are needed to guide policy (Kirigia \& Muthuri, 2020a, 2020b, 2020c, 2020d, 2020e; 
Kirigia, Muthuri, \& Nkanata, 2020).

\section{Acknowledgements}

We owe profound gratitude to Jehovah Jireh for meeting all our needs in the entire process of conceiving and writing this paper. This paper is dedicated to health workers, who are the frontline soldiers in the war against COVID-19 in the Continent. The views expressed in this paper are only those of authors and should not be attributed to their institutions of affiliation.

\section{Authors' Contributions}

JMK, RNDKM, LHKN, and NGM designed the study; reviewed the literature; extracted data from the international databases; analyzed and interpreted findings; and drafted the manuscript together. All the authors approved the version of the manuscript submitted.

\section{Funding}

The study did not receive funding from any source.

\section{Conflicts of Interest}

The authors declare no conflicts of interest regarding the publication of this paper.

\section{References}

Cookson, R., Griffin, S., Norheim, O. F., \& Culyer, A. J. (2020). Distributional Cost-Effectiveness Analysis: Quantifying Health Equity Impacts and Trade-Offs. Oxford: Oxford University Press.

Drummond, M. F., Sculpher, M. J., Torrance, G. W., O’Brien, B. J., \& Stoddard, G. L. (2007). Methods for the Economic Evaluation of Health Care Programmes. Oxford: Oxford University Press.

International Monetary Fund (IMF) (2020). World Economic Outlook Database. https://www.imf.org/external/pubs/ft/weo/2019/02/weodata/index.aspx

Jones-Lee, M. W. (1985). The Value of Life and Safety: A Survey of Recent Developments. The Geneva Papers on Risk and Insurance: Issues and Practice, 10, 141-173. https://doi.org/10.1057/gpp.1985.13

Kirigia, J. M. (2009). Economic Evaluation of Public Health Problems in Sub-Saharan Africa. Nairobi: University of Nairobi Press.

Kirigia, J. M., \& Muthuri, R. D. K. M. (2020a). The Dollar Value of Human Life Losses Associated with COVID-19 in Canada. Pharmaceutical and Biomedical Research, in press. http://pbr.mazums.ac.ir/index.php?sid=1\&slc_lang=en

Kirigia, J. M., \& Muthuri, R. N. D. K. (2020b). The Fiscal Value of Human Lives Lost from Coronavirus Disease (COVID-19) in China. BMC Research Notes, 13, Article No. 198. https://doi.org/10.1186/s13104-020-05044-y

Kirigia, J. M., \& Muthuri, R. N. D. K. (2020c). The Discounted Money Value of Human Lives Lost Due to COVID-19 in Spain. Journal of Health Research, 34, 455-460. 
https://doi.org/10.1108/JHR-04-2020-0116

Kirigia, J. M., \& Muthuri, R. D. K. M. (2020d). The Present Value of Human Lives Lost Due to COVID-19 in the United Kingdom (UK). Pharmaceutical and Biomedical Research, in press. http://pbr.mazums.ac.ir/index.php?sid=1\&slc_lang=en

Kirigia, J. M., \& Muthuri, R. N. D. K. (2020e). Discounted Monetary Value of Human Lives Lost Due to COVID-19 in the USA as of 3 May 2020. IOSR Journal of Dental and Medical Sciences, 19, 51-54.

Kirigia, E. K., Rutere, A. M., Muthuri, R. N. D. K., \& Kirigia, J. M. (2020). Universal health Coverage Gaps in Africa: A Challenge for COVID-19 Management. IOSR Journal of Dental and Medical Sciences, 19, 42-44.

Kirigia, J. M., Muthuri, R. N. D. K., \& Nkanata, L. H. K. (2020). The Monetary Value of Human Life Losses Associated with COVID-19 in Turkey. Emerald Open Research, 2, 44. https://doi.org/10.35241/emeraldopenres.13822.1

Landefeld, J. S., \& Seskin, E. P. (1982). The Economic Value of Life: Linking Theory to Practice. The American Journal of Public Health, 72, 555-566. https://doi.org/10.2105/AJPH.72.6.555

Rice, D. P. (2000). Cost of Illness Studies: What Is Good about Them? Injury Prevention, 6, 177-179.

Rutere, A. M., Muthuri, R. N. D. K., Kirigia, E. K., \& Kirigia, J. M. (2020). Gaps in Coverage of Water and Sanitation in Africa: Challenges for Practicing Safe Hand Hygiene to Combat Spread of COVID-19. IOSR Journal of Environmental Science, Toxicology and Food Technology, 14, 22-25.

Statista (2020). Number of Coronavirus (COVID-19) Deaths in South Africa in 2020, by age.

https://www.statista.com/statistics/1127259/coronavirus-covid-19-deaths-by-age-south -africa/

United Nations (UN) (1948). International Bill of Human Rights: A Universal Declaration of Human Rights. General Assembly Resolution A217(III), New York: United Nations.

Weisbrod, B. A. (1961). The Valuation of Human Capital. Journal of Political Economy, 69, 425-436. https://doi.org/10.1086/258535

WHO (2009a). WHO Guide to Identifying the Economic Consequences of Disease and Injury. Geneva: World Health Organization.

WHO (2009b). Reducing Health Inequities through Action on the Social Determinants of Health. World Health Assembly Resolution WHA62.14, Geneva: World Health Organization.

WHO (2010). A Strategy for Addressing Key Determinants of Health in the African Region. Regional Committee for Africa Resolution AFR/RC60/R1, Brazzaville: World Health Organization.

WHO (2012a). Outcome of the World Conference on Social Determinants of Health. World Health Assembly Resolution WHA65.8, Geneva: World Health Organization.

WHO (2012b). Health Promotion: Strategy for the African Region. Regional Committee for Africa Resolution AFR/RC62/R4, Brazzaville: World Health Organization.

WHO (2013). IHR Core Capacity Monitoring Framework: Checklist and Indicators for Monitoring Progress in the Development of IHR Core Capacities in States Parties. Geneva: World Health Organization.

WHO (2019). World Health Statistics 2019: Monitoring Health for the SDGs. Geneva: 
World Health Organization.

WHO (2020a). World Health Statistics 2020: Monitoring Health for the SDGs. Geneva: World Health Organization.

WHO (2020b). WHO Global Health Expenditure Database. https://apps.who.int/nha/database/Select/Indicators/en

WHO and The World Bank (2017). Tracking Universal Health Coverage: 2017 Global Monitoring Report. Geneva \& Washington DC: World Health Organization.

Worldometer (2020). COVID-19 Coronavirus Pandemic Database.

https://www.worldometers.info/coronavirus/ 


\section{Supplement}

Table S1. Names of countries and territories in the Africa continent.

\begin{tabular}{|c|}
\hline Country and Territories Names \\
\hline Algeria \\
\hline Angola \\
\hline Benin \\
\hline Botswana \\
\hline Burkina Faso \\
\hline Burundi \\
\hline Cameroon \\
\hline Cabo Verde \\
\hline Central African Republic \\
\hline Chad \\
\hline Comoros \\
\hline Congo \\
\hline Côte d'Ivoire \\
\hline Democratic Republic of the Congo \\
\hline Equatorial Guinea \\
\hline Eritrea \\
\hline Ethiopia \\
\hline Gabon \\
\hline Gambia \\
\hline Ghana \\
\hline Guinea \\
\hline Guinea-Bissau \\
\hline Kenya \\
\hline Lesotho \\
\hline Liberia \\
\hline Madagascar \\
\hline Malawi \\
\hline Mali \\
\hline Mauritania \\
\hline Mauritius \\
\hline Mozambique \\
\hline Namibia \\
\hline Niger \\
\hline Nigeria \\
\hline Rwanda \\
\hline
\end{tabular}




\section{Continued}

Sao Tome and Principe

Senegal

Seychelles

Sierra Leone

South Africa

Swaziland (Eswatini)

Togo

Uganda

United Republic of Tanzania

Zambia

Zimbabwe

South Sudan

Djibouti

Egypt

Libya

Morocco

Somalia

Sudan

Tunisia

Sahrawi Arab Democratic Republic (Western Sahara)

Territories

Reunion

Mayotte

Source: Worldometer (2020).

Table S2. Africa continent countries average life expectancies at birth in 2020 .

\begin{tabular}{cc}
\hline Country & Average life expectancy in 2020 \\
Algeria & 77.5 \\
Angola & 62.2 \\
Benin & 62.8 \\
Botswana & 69.9 \\
Burkina Faso & 63 \\
Burundi & 62.7 \\
Cameroon & 60.3 \\
Cape Verde & 73.6 \\
Central African Republic & 54.4 \\
\hline
\end{tabular}




\section{Continued}

\begin{tabular}{|c|c|}
\hline Chad & 55.2 \\
\hline Comoros & 65 \\
\hline Congo & 65.2 \\
\hline Côte d'Ivoire & 58.8 \\
\hline Dem. Rep. of the Congo & 61.6 \\
\hline Equatorial Guinea & 59.8 \\
\hline Eritrea & 67.5 \\
\hline Ethiopia & 67.8 \\
\hline Gabon & 67 \\
\hline Gambia & 63.3 \\
\hline Ghana & 64.9 \\
\hline Guinea & 62.6 \\
\hline Guinea-Bissau & 59.4 \\
\hline Kenya & 67.5 \\
\hline Lesotho & 55.7 \\
\hline Liberia & 65 \\
\hline Madagascar & 68.2 \\
\hline Malawi & 65.6 \\
\hline Mali & 60.5 \\
\hline Mauritania & 65.6 \\
\hline Mauritius & 75.5 \\
\hline Mozambique & 62.1 \\
\hline Namibia & 64.9 \\
\hline Niger & 63.6 \\
\hline Nigeria & 55.8 \\
\hline Rwanda & 70 \\
\hline Sao Tome and Principe & 71 \\
\hline Senegal & 68.9 \\
\hline Seychelles & 73.7 \\
\hline Sierra Leone & 55.9 \\
\hline South Africa & 64.9 \\
\hline Swaziland & 61.1 \\
\hline Togo & 62.1 \\
\hline Uganda & 64.4 \\
\hline United Republic of Tanzania & 66.4 \\
\hline Zambia & 64.7 \\
\hline Zimbabwe & 62.2 \\
\hline
\end{tabular}




\section{Continued}

\begin{tabular}{cc}
\hline South Sudan & 58.7 \\
Djibouti & 67.9 \\
Egypt & 72.5 \\
Libya & 73.4 \\
Morocco & 77.4 \\
Somalia & 58.3 \\
Sudan & 66.0 \\
Tunisia & 77.4 \\
Sahrawi Arab Democratic Republic (Western Sahara) & 71.1 \\
Territories & \\
Reunion & 82 \\
Mayotte & 80 \\
\hline
\end{tabular}

Source: Worldometer (2020).

Table S3. Africa countries per capita gross domestic product (2020, Int\$ or PPP).

\begin{tabular}{|c|c|}
\hline Country & Per capita gross domestic product (Int\$) \\
\hline Algeria & 16,091 \\
\hline Angola & 6763 \\
\hline Benin & 3648 \\
\hline Botswana & 19,388 \\
\hline Burkina Faso & 2181 \\
\hline Burundi & 724 \\
\hline Cameroon & 4099 \\
\hline Cape Verde & 8176 \\
\hline Central African Republic & 864 \\
\hline Chad & 2603 \\
\hline Comoros & 2898 \\
\hline Democratic Republic of the Congo & 873 \\
\hline Congo & 7336 \\
\hline Côte d'Ivoire & 4754 \\
\hline Equatorial Guinea & 19,961 \\
\hline Eritrea & 1103 \\
\hline Ethiopia & 2702 \\
\hline Gabon & 19,839 \\
\hline Gambia & 2892 \\
\hline Ghana & 7343 \\
\hline
\end{tabular}




\section{Continued}

\begin{tabular}{|c|c|}
\hline Guinea & 2574 \\
\hline Guinea-Bissau & 2113 \\
\hline Kenya & 4078 \\
\hline Lesotho & 3655 \\
\hline Liberia & 1428 \\
\hline Madagascar & 1776 \\
\hline Malawi & 1292 \\
\hline Mali & 2569 \\
\hline Mauritania & 5158 \\
\hline Mauritius & 26,461 \\
\hline Mozambique & 1372 \\
\hline Namibia & 11,451 \\
\hline Niger & 1152 \\
\hline Nigeria & 6172 \\
\hline Rwanda & 2642 \\
\hline São Tomé and Príncipe & 3499 \\
\hline Senegal & 4079 \\
\hline Seychelles & 33,118 \\
\hline Sierra Leone & 1765 \\
\hline South Africa & 13,965 \\
\hline Swaziland & 11,319 \\
\hline Tanzania & 3562 \\
\hline Togo & 1913 \\
\hline Uganda & 2753 \\
\hline Zambia & 4174 \\
\hline Zimbabwe & 2778 \\
\hline South Sudan & 1715 \\
\hline Djibouti & 5855 \\
\hline Egypt & 14,800 \\
\hline Libya & 9446 \\
\hline Morocco & 9667 \\
\hline Somalia & 904 \\
\hline Sudan & 3986 \\
\hline Tunisia & 13,093 \\
\hline
\end{tabular}

Source: International Monetary Fund (IMF) (2020). Note: Int\$: International Dollars (Int\$). PPP: Purchasing-power-parity. 
Table S4. Africa countries current health expenditure per capita.

\begin{tabular}{|c|c|}
\hline Country & Current health expenditure per person (Int\$) \\
\hline Algeria & 975 \\
\hline Angola & 186 \\
\hline Benin & 85 \\
\hline Botswana & 1044 \\
\hline Burkina Faso & 129 \\
\hline Burundi & 59 \\
\hline Cameroon & 174 \\
\hline Cabo Verde & 357 \\
\hline Central African Republic & 42 \\
\hline Chad & 87 \\
\hline Comoros & 123 \\
\hline Democratic Republic of the Congo & 37 \\
\hline Congo & 165 \\
\hline Cote d'Ivoire & 176 \\
\hline Equatorial Guinea & 759 \\
\hline Eritrea & 59 \\
\hline Ethiopia & 67 \\
\hline Gabon & 500 \\
\hline Gambia & 56 \\
\hline Ghana & 147 \\
\hline Guinea & 89 \\
\hline Guinea-Bissau & 123 \\
\hline Kenya & 158 \\
\hline Lesotho & 266 \\
\hline Liberia & 105 \\
\hline Madagascar & 85 \\
\hline Malawi & 115 \\
\hline Mali & 84 \\
\hline Mauritania & 170 \\
\hline Mauritius & 1278 \\
\hline Mozambique & 62 \\
\hline Namibia & 895 \\
\hline Niger & 79 \\
\hline Nigeria & 221 \\
\hline Rwanda & 134 \\
\hline Sao Tome and Principe & 134 \\
\hline
\end{tabular}




\section{Continued}

\begin{tabular}{cc}
\hline Senegal & 143 \\
Seychelles & 1485 \\
Sierra Leone & 205 \\
South Africa & 1098 \\
Swaziland & 600 \\
Tanzania & 104 \\
Togo & 104 \\
Uganda & 123 \\
Zambia & 180 \\
Zimbabwe & 201 \\
South Sudan & 176 \\
Djibouti & 117 \\
Egypt & 614 \\
Libya & 429 \\
Morocco & 438 \\
Somalia & 275 \\
Sudan & 314 \\
Tunisia & 863 \\
\hline
\end{tabular}

Source: WHO (2020b).

Table S5. Africa countries net gross domestic product per capita in 2020.

\begin{tabular}{cc}
\hline Countries & Net GDP per capita (Int\$) \\
\hline Algeria & 15,116 \\
Angola & 6577 \\
Benin & 3563 \\
Botswana & 18,343 \\
Burkina Faso & 2052 \\
Burundi & 664 \\
Cameroon & 3926 \\
Cabo Verde & 7819 \\
Central African Republic & 822 \\
Chad & 2515 \\
Comoros & 2775 \\
Congo & 7172 \\
Côte d'Ivoire & 4578 \\
Equatorial Guinea & 836 \\
Eritrea & 19,202 \\
Democratic Republic of the Congo & 1043 \\
\hline
\end{tabular}




\section{Continued}

\begin{tabular}{|c|c|}
\hline Ethiopia & 2635 \\
\hline Gabon & 19,340 \\
\hline Gambia & 2836 \\
\hline Ghana & 7196 \\
\hline Guinea & 2485 \\
\hline Guinea-Bissau & 1990 \\
\hline Kenya & 3920 \\
\hline Lesotho & 3390 \\
\hline Liberia & 1323 \\
\hline Madagascar & 1691 \\
\hline Malawi & 1178 \\
\hline Mali & 2485 \\
\hline Mauritania & 4988 \\
\hline Mauritius & 25,183 \\
\hline Mozambique & 1311 \\
\hline Namibia & 10,555 \\
\hline Niger & 1073 \\
\hline Nigeria & 5951 \\
\hline Rwanda & 2507 \\
\hline Sao Tome and Principe & 3364 \\
\hline Senegal & 3935 \\
\hline Seychelles & 31,633 \\
\hline Sierra Leone & 1560 \\
\hline South Africa & 12,867 \\
\hline South Sudan & 1539 \\
\hline Swaziland & 10,719 \\
\hline Togo & 1809 \\
\hline Uganda & 2630 \\
\hline Tanzania & 3457 \\
\hline Zambia & 3994 \\
\hline Zimbabwe & 2577 \\
\hline Djibouti & 5738 \\
\hline Egypt & 14,187 \\
\hline Libya & 9017 \\
\hline Morocco & 9229 \\
\hline Somalia & 629 \\
\hline Sudan & 3672 \\
\hline Tunisia & 12,229 \\
\hline
\end{tabular}

Source: Authors estimates using data from International Monetary Fund (IMF) (2020) and WHO (2020b). Note: Net GDP per capita equals GDP per capita minus current health expenditure per person. 
Table S6. Africa countries coronavirus disease deaths as of 1 August 2020.

\begin{tabular}{|c|c|}
\hline Countries & COVID19 Deaths in 2020: 1 August 2020 \\
\hline Algeria & 1210 \\
\hline Angola & 52 \\
\hline Benin & 36 \\
\hline Botswana & 2 \\
\hline Burkina Faso & 53 \\
\hline Burundi & 1 \\
\hline Cameroon & 391 \\
\hline Cabo Verde & 23 \\
\hline CAR & 59 \\
\hline Chad & 75 \\
\hline Comoros & 7 \\
\hline Congo & 54 \\
\hline Cote d'Ivoire & 102 \\
\hline Democratic Republic of Congo (DRC) & 215 \\
\hline Djibouti & 58 \\
\hline Egypt & 4805 \\
\hline Equatorial Guinea & 83 \\
\hline Eritrea & 0 \\
\hline Ethiopia & 274 \\
\hline Gabon & 49 \\
\hline Gambia & 9 \\
\hline Ghana & 182 \\
\hline Guinea & 46 \\
\hline Guinea-Bissau & 26 \\
\hline Kenya & 341 \\
\hline Lesotho & 13 \\
\hline Liberia & 75 \\
\hline Libya & 74 \\
\hline Madagascar & 106 \\
\hline Malawi & 114 \\
\hline Mali & 124 \\
\hline Mauritania & 157 \\
\hline Mauritius & 10 \\
\hline Morocco & 353 \\
\hline Mozambique & 11 \\
\hline Namibia & 10 \\
\hline
\end{tabular}




\section{Continued}

\begin{tabular}{cc} 
Niger & 69 \\
Nigeria & 879 \\
Rwanda & 5 \\
STP & 15 \\
Senegal & 205 \\
Seychelles & 0 \\
Sierra Leone & 67 \\
Somalia & 93 \\
South Africa & 8005 \\
South Sudan & 46 \\
Sudan & 746 \\
Swaziland/Eswatini & 41 \\
Togo & 19 \\
Tunisia & 50 \\
Uganda & 39 \\
Tanzania & 19726 \\
Zambia & 67 \\
Zimbabwe & 21 \\
Reunion & 151 \\
Mayotte & 39 \\
Western Sahara & \\
TOTAL & 5 \\
\hline
\end{tabular}

Source: Worldometer (2020).

Table S7. Proportions used to share COVID-19 deaths across eight age groups.

\begin{tabular}{ccc}
\hline Age brackets & $\begin{array}{c}\text { (A) COVID-19 deaths in } \\
\text { South Africa as of as of 22 June 2020 }\end{array}$ & (C). Proportion [C = A/B] \\
\hline $0-9$ & 3 & 0.001563314 \\
$10-19$ & 5 & 0.002605524 \\
$20-29$ & 26 & 0.013548723 \\
$30-39$ & 116 & 0.06044815 \\
$40-49$ & 244 & 0.127149557 \\
$50-59$ & 471 & 0.245440334 \\
$60-69$ & 506 & 0.263678999 \\
70 \& above & 548 & 0.285565399 \\
(B) TOTAL & 1919 & \\
\hline
\end{tabular}

Source: Statista (2020). Note: The 11 deaths whose age was unknown were not included in calculations of the proportions. 
Table S8. Africa continent countries years of life lost from COVID-19 by 1st August 2020.

\begin{tabular}{|c|c|c|c|c|c|c|c|c|c|}
\hline \multirow{2}{*}{ Countries } & \multicolumn{8}{|c|}{ Years of life lost per age group } & \multirow[b]{2}{*}{ TOTAL } \\
\hline & $0-9$ & $10-19$ & $20-29$ & $30-39$ & $40-49$ & $50-59$ & $60-69$ & $70+$ & \\
\hline Algeria & 138 & 199 & 869 & 3145 & 5077 & 6831 & 4148 & 2592 & 22,998 \\
\hline Angola & 5 & 6 & 27 & 87 & 117 & 99 & - & - & 341 \\
\hline Benin & 3 & 5 & 19 & 62 & 84 & 74 & - & - & 246 \\
\hline Botswana & 0 & 0 & 1 & 4 & 6 & 8 & 3 & - & 23 \\
\hline Burkina Faso & 5 & 7 & 28 & 91 & 125 & 110 & - & - & 365 \\
\hline Burundi & 0 & 0 & 1 & 2 & 2 & 2 & - & - & 7 \\
\hline Cameroon & 34 & 47 & 190 & 610 & 786 & 559 & - & - & 2226 \\
\hline Cape Verde & 2 & 4 & 15 & 54 & 85 & 108 & 55 & 24 & 347 \\
\hline $\begin{array}{c}\text { Central African } \\
\text { Republic }\end{array}$ & 5 & 6 & 24 & 71 & 74 & - & - & - & 179 \\
\hline Chad & 6 & 8 & 31 & 94 & 102 & 12 & - & - & 253 \\
\hline Comoros & 1 & 1 & 4 & 13 & 18 & 18 & 1 & - & 56 \\
\hline Congo & 5 & 7 & 30 & 100 & 142 & 142 & 10 & - & 437 \\
\hline Cote D'Ivoire & 9 & 12 & 47 & 150 & 185 & 106 & - & - & 508 \\
\hline DRC & 19 & 26 & 108 & 352 & 467 & 375 & - & - & 1348 \\
\hline Equatorial Guinea & 7 & 10 & 40 & 127 & 162 & 108 & - & - & 454 \\
\hline Eritrea & - & - & - & - & - & - & - & - & - \\
\hline Ethiopia & 27 & 38 & 161 & 552 & 812 & 895 & 239 & - & 2724 \\
\hline Gabon & 5 & 7 & 28 & 96 & 140 & 151 & 33 & - & 460 \\
\hline Gambia & 1 & 1 & 5 & 16 & 21 & 19 & - & - & 63 \\
\hline Ghana & 17 & 24 & 100 & 335 & 473 & 466 & 21 & - & 1436 \\
\hline Guinea & 4 & 6 & 24 & 78 & 106 & 92 & - & - & 310 \\
\hline Guinea Bissau & 2 & 3 & 12 & 39 & 49 & 31 & - & - & 137 \\
\hline Kenya & 34 & 47 & 199 & 680 & 996 & 1086 & 267 & - & 3307 \\
\hline Lesotho & 1 & 1 & 5 & 17 & 18 & 4 & - & - & 47 \\
\hline Liberia & 7 & 10 & 41 & 138 & 195 & 193 & 10 & - & 595 \\
\hline Madagascar & 11 & 15 & 63 & 216 & 320 & 357 & 104 & - & 1084 \\
\hline Malawi & 11 & 15 & 64 & 214 & 306 & 311 & 34 & - & 955 \\
\hline Mali & 11 & 15 & 61 & 195 & 253 & 184 & - & - & 718 \\
\hline Mauritania & 15 & 21 & 87 & 295 & 421 & 427 & 44 & - & 1310 \\
\hline Mauritius & 1 & 2 & 7 & 25 & 39 & 52 & 29 & 16 & 170 \\
\hline Mozambique & 1 & 1 & 6 & 18 & 25 & 21 & - & - & 72 \\
\hline Namibia & 1 & 1 & 5 & 18 & 26 & 25 & 1 & - & 78 \\
\hline Niger & 6 & 9 & 37 & 121 & 168 & 154 & - & - & 495 \\
\hline
\end{tabular}




\section{Continued}

\begin{tabular}{|c|c|c|c|c|c|c|c|c|c|}
\hline Nigeria & 70 & 94 & 372 & 1129 & 1257 & 270 & - & - & 3193 \\
\hline Rwanda & 1 & 1 & 3 & 11 & 16 & 19 & 7 & - & 58 \\
\hline STP & 2 & 2 & 9 & 33 & 51 & 61 & 26 & 4 & 188 \\
\hline Senegal & 21 & 29 & 123 & 426 & 635 & 723 & 236 & - & 2193 \\
\hline Seychelles & - & - & - & - & - & - & - & - & - \\
\hline Sierra Leone & 5 & 7 & 29 & 87 & 97 & 23 & - & - & 249 \\
\hline South Africa & 756 & 1051 & 4380 & 14,701 & 20,743 & 20,394 & 802 & - & 62,826 \\
\hline South Sudan & 4 & 5 & 21 & 67 & 83 & 48 & - & - & 229 \\
\hline Swaziland & 4 & 5 & 20 & 66 & 86 & 66 & - & - & 247 \\
\hline Tanzania & 2 & 3 & 12 & 40 & 58 & 61 & 10 & - & 187 \\
\hline Togo & 2 & 2 & 10 & 32 & 43 & 36 & - & - & 124 \\
\hline Uganda & 0 & 0 & 2 & 5 & 8 & 7 & - & - & 23 \\
\hline Zambia & 14 & 20 & 82 & 276 & 388 & 378 & 8 & - & 1166 \\
\hline Zimbabwe & 6 & 8 & 34 & 112 & 150 & 126 & - & - & 437 \\
\hline Djibouti & 6 & 8 & 34 & 117 & 172 & 190 & 52 & - & 579 \\
\hline Egypt & 511 & 727 & 3127 & 11,049 & 17,131 & 21,275 & 10,186 & 3485 & 67,492 \\
\hline Libya & 8 & 11 & 49 & 174 & 272 & 344 & 174 & 73 & 1106 \\
\hline Morocco & 40 & 58 & 253 & 916 & 1478 & 1987 & 1204 & 749 & 6684 \\
\hline Somalia & 8 & 11 & 43 & 134 & 164 & 88 & - & - & 446 \\
\hline Sudan & 72 & 100 & 420 & 1421 & 2040 & 2107 & 297 & - & 6457 \\
\hline Tunisia & 6 & 8 & 36 & 130 & 209 & 281 & 170 & 105 & 943 \\
\hline TOTAL & 1930 & 2704 & 11,395 & 38,941 & 56,885 & 61,502 & 18,170 & 7047 & 198,575 \\
\hline Percent & 1.0 & 1.4 & 5.7 & 19.6 & 28.6 & 31.0 & 9.2 & 3.5 & 100.0 \\
\hline
\end{tabular}

Source: Author estimates. Note: Years of life lost (YLL) in an age group equals national life expectancy minus average age at onset of death from COVID-19 in an age group. 